\title{
The Effect of Advertising on Customer Engagement (Study of Ad Oronamin C in Generation Z)
}

\author{
Mitha Daven ${ }^{1}$ Wulan Purnama Sari ${ }^{1 *}$ \\ ${ }^{1}$ Faculty of Communication Tarumanagara University. Jakarta Barat 11440. Indonesia \\ *Corresponding author. Email: wulanp@fikom.untar.ac.id
}

\begin{abstract}
Advertising on YouTube is a familiar marketing tool for consumers to see. Social media is a platform that is easy to access using the internet network. One of the platforms that is often used by generation $\mathrm{Z}$ children is YouTube. Everyone can easily use the YouTube app to view the videos they like. Oronamin $C$ is a health drink originating from Japan. One of the marketing strategies implemented by Oronamin $\mathrm{C}$ is to make a video advertisement entitled "Oronamin C Desktop Adventure" to convey the messages contained in the Oronamin C drink. This research was conducted to determine the effect of advertising on customer engagement. This study uses a quantitative approach with descriptive research methods. This study uses a survey method to collect data. This research was conducted by distributing pretest questionnaires to 30 respondents who had watched the desktop version of the Oronamin $\mathrm{C}$ ad and then tested its validity and reliability. After that, a valid statement will be distributed again by means of a post-test test to 100 respondents. The theory used in this research is advertising and customer engagement. The validity technique used in this research is the classical assumption test, correlation test, simple linear regression test, T-test, descriptive analysis, and determination coefficient analysis. With the results of the T-test of 9,484>1,984, the results of the correlation test are $0.692>0.05$, which means that the effect of advertising on customer engagement is strong. So that the results obtained from this study can show that advertisements have an effect on customer engagement from YouTube ads Oronamin C Desktop Version.
\end{abstract}

Keywords: Customer engagement, advertising, oronamine c, youTube

\section{INTRODUCTION}

This development in the digital era has made advertisers take advantage of the digital world as a promotional medium and a place to convey messages to consumers. The method used by advertisers of a product is to manage and convey information about a product to consumers quickly, namely creating advertisements. According to Arifin's opinion in the journal [1] advertising is a strategic way to introduce and explain the product you want to market. Advertising can easily be spread through the media, the media is very important in publishing or communicating advertisements to the general public.

The way to advertise a product can be through various media such as social and digital media. Social and digital media make it easy for advertisers to convey messages and information about a product to consumers, besides that, social media can also build relationships with consumers.

According to [2] Social media was chosen because it allows someone to market their products in new ways. In $2016 \mathrm{We}$ Are Social stated that of the 7.395 billion world population, 2.307 billion people actively use social media. In Southeast Asia, 30 percent of the total population is active on the internet.
Directly in this digital era, there are many advertisers who advertise their products through YouTube social media, YouTube is a platform that allows users to upload, watch or share videos. Advertisers take advantage of the platform to advertise their products by making creative videos to increase the brand awareness of their viewers.

In 2017 tirto.id conducted research on 1,201 respondents aged 7-21 years (generation z). As many as $41.3 \%$ of them choose social media as an easily accessible media for information. Generation $\mathrm{Z}$ is the generation after generation Y, people who are vulnerable when they were born in 1996 to 2010. This generation is no stranger to playing social media such as Instagram, Line, WhatsApp, Facebook, Twitter and YouTube. most of them get information through social media. [3]

One of the advantages of YouTube is that it can convey messages with visuals, motion and audio, many beverage and food companies choose to advertise their products. The use of digital marketing is indispensable in developing the business world and can also add numbers from the target market. According to Guesalaga in the journal [4] customer engagement on social media is defined as loyal consumers of companies that are active in social media. The Marketing Science Insititude (MSI) argues that customer engagement 
is a form of consumer behavior towards brands in purchasing from consumer personal motivation.

Oronamin $\mathrm{C}$ is one of the vitamin drink companies that promote through social media, namely YouTube. Oronamin C uploaded a video entitled "Oronamin C Desktop Adventure" which tells of someone who lost his Oronamin $\mathrm{C}$ drink, then his friends helped find it through a desktop image, this video has premiered on June 15, 2020. In addition, this video is also welcomed and has lots of positive comments.

Oronamin $\mathrm{C}$ is a video that is quite interesting for the advertising world because Oronamin $\mathrm{C}$ relies on animation which is quite influential in the desktop Adventure version of Oronamin C's ad. So the researcher decided to do a research with the title Effect of Advertising on Customer Engagement (Study of Oronamine C Ad Desktop Adventure Version in Generation Z).

\subsection{Related Work}

The author uses previous research by [5], the purpose of his research is to find out that digital advertising affects product purchasing decisions at the JD.ID company. The difference is in the variable $y$. Based on the results of the analysis, there is an influence between digital advertising on product buying decisions. Then [6] "the aim of the researcher is to know that content marketing and event marketing have an effect on customer engagement. The difference is in the variable $\mathrm{x}$. Based on the results of the analysis, content marketing, and event marketing have a significant effect on customer engagement. Then [7] The difference is in the variables used and the research method, in this study using qualitative methods.

According to Hakim in [8] there are 6 dimensions that can measure advertising, namely: (1) Simple: The advertisement served should be simple and understandable at one glance of the ad; (2) Unexpected: An unexpected or unique advertisement can stick in the minds of consumers; (3) Persuasive: Persuasive advertising can convince consumers about a product, have the influence to persuade consumers; (4) Entertaining: Ads that are made to entertain consumers, entertaining doesn't have to be funny but has a deeper meaning; (5) Relevant: Ads that are presented to consumers in a very great and unique way sometimes come out of the context of a product, but must remain in touch with the brand at the end; (6) Acceptable : Advertisements accepted by consumers, advertisements that contain public reactions because they exceed values, creative ideas that are still limited by societal norms.

According to the adaptation of Dessart et al in [9] there are 3 dimensions of Customer Engagement, namely: (1) Affective: Affective is that customers feel enthusiastic and satisfied when interacting with company content. Content that is capable of satisfying to get more attention from consumers; (2) Cognitive: Cognitive involvement is the level of attention and absorption of information in the content. Consumer attention to interesting and entertaining content. When consumers pay attention to the content, consumers will absorb information about a product.
Consumers who absorb information tend to share content online as well as offline.; (3) Behavior: Behavioral engagement is in the form of sharing content, studying and supporting content. This form of behavior depends on the exchange of experiences between companies and consumers.

\subsection{Our Contribution}

By conducting this research, authors hope to give contributions : (1) This research is expected to be useful for references related to the field of communication science, especially in the field of advertising, especially regarding the effect of advertising on customer engagement in generation Z; (3) The results of this study are expected to increase knowledge and insight for readers who need references in the field of advertising both from the content and systematics used. And aim to find out the effect of YouTube Oronamin C Desktop ads on viewers' attitudes for the Otsuka brand.

\subsection{Paper Structure}

This paper is organized into several sections, first is an introduction that explains the reason and purposes of conducting this research. Second, the related word explains the theoretical framework using in this research. Third, the contribution and aim of this research. Fourth, research methods including research approach, population, and sample. Fifth, finding and discussion of this research along with a conclusion.

\section{METHODS}

This research uses a quantitative approach and a descriptive approach. This quantitative approach method is in accordance with the aim of knowing and analyzing the effect of advertising on customer engagement. The data collection used in this study is a survey because it wants to examine advertisements that focus on YouTube social media on customer engagement.

This study uses the population of viewers who have watched Oronamin $\mathrm{C}$ advertisements and Generation Z according to [3] 2017 people who are vulnerable at birth in 1996 - 2010, namely the age of 24-20 years, the population used by people who have watched Oronamin advertisements C on YouTube and 10-24 years old.

The research object is the influence of advertising on customer engagement, the subjects in this study are the audience who have watched Oronamin $\mathrm{C}$ ads. If the population is large, it is impossible for the researcher to study everything in the population, for example, due to limited time, energy, and funds, the researcher takes the sample. of that population.

The sample according to [10] is the number and characteristics possessed by the population that has been 
studied from the population and the conclusion applies to that population, therefore the sample taken must be able to represent that population.

According to Roscoe in [10], the appropriate sample size for a researcher is 30 to 500 samples. Therefore, this study will use a sample size of 100 respondents using the sample criteria that have been determined.

The technique that researchers will use for sampling with non-probability sampling techniques is a sampling technique that does not provide equal opportunities for each element of the population to be selected as respondents [10]. From this technique, the researcher will use purposive sampling. According to [10] Purposive Sampling is a sample determination technique with certain criteria.

This study will pretest as many as 30 respondents then the results of this pretest will be tested for validity and reliability test, both tests will be the key to whether or not treatment is needed on the questionnaire. If the results are invalid and unreliable at the pretest, then treatment will be carried out for deleting the statement items in the questionnaire. Then if the statements are valid and reliable, the researcher will do a post-test on 100 respondents.

This study uses validity techniques, namely validity and reliability tests. While the data analysis technique used is descriptive statistical analysis, classical assumption test, correlation test, simple linear regression test, and determination analysis. This study processes and analyzes data using electronic data processing methods assisted by the IBM SPSS statistic 20 program. Activities carried out in data processing consist of grouping the variables to be processed and performing calculations for hypothesis testing.

\section{FINDINGS AND DISCUSSION}

\subsection{Validity and Reliability Test}

The purpose of this study is to explain whether there is an effect between the Desktop version of Oronamin C Ads and Customer Engagement. This study used a sample of 100 respondents. The results that have been tested indicate that there is an influence between advertising having an influence on Customer Engagement.

From testing the validity of this pretest section using 30 respondents with a significant level of $5 \%$ and $\mathrm{R}$ table 0.374 . After being tested, it can be seen that there are 4 invalid statements so that the researcher takes the treatment by removing the invalid statements in statements $1,5,10$, and 12. Furthermore, the researcher conducts posttest testing by distributing questionnaires to 100 respondents containing 22 statements containing 8 statements of variable $\mathrm{X}$ and 14 statements of variable Y. From the calculation of the validity of the posttest section using 100 respondents with a significant level of $5 \%$ and $\mathrm{R}$ table 0.195 . After testing the validity of these data, 22 statements were tested valid.
From the reliability test that the researcher got at the pretest with 30 respondents, it was 0.920 , so it could be concluded that $0.920>0.8$ and the statement of this research was good reliable. Then the researcher did the posttest, what the researcher got in the posttest with 100 respondents was 0.913 , so it could be concluded that $0.913>0.8$ and the statement of this study had good reliability.

\subsection{Respondent Characteristics}

From the results of the questionnaire that was distributed to 100 respondents with the criteria of having watched Oronamin $\mathrm{C}$ desktop version, domiciled in Jakarta and its surroundings, aged 10-24 years (Generation Z), the researchers obtained data on the characteristics of respondents consisting of age and gender as follows :

a. Gender of 100 respondents: respondents based on "gender", namely 59 respondents (59\%) who are female. And as many as 41 respondents $(41 \%)$ are male.

b. b. Age of 100 respondents: respondents based on "age" are 76 respondents $(76 \%)$ aged $21-24$ years. And as many as 24 respondents (24\%) aged 17-20 years.
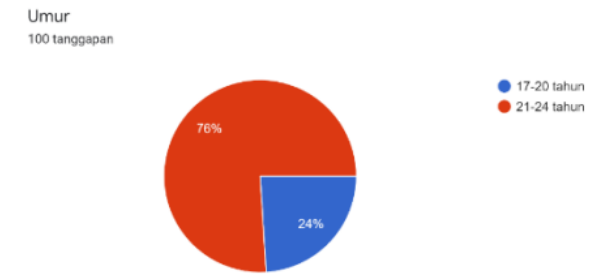

Figure 1 Respondent characteristics

\subsection{Descriptive Statistical Analysis}

From the results of the descriptive analysis in this study it is known that the third statement, namely the advertising variable, can be seen quite well because it has a good mean score with the highest score of 3.49. The statement is "The content presented by Oronamin $\mathrm{C}$ advertisements is different from other advertisements."

This statement is in the Unexpected dimension on the Uniqueness indicator. According to [8] Unexpected is an unexpected or unique advertisement that can stick in the minds of consumers. So that the ads served by Oronamin C on YouTube look interesting and different from advertisements for other products.

Meanwhile, the lowest score is in statement 21, namely 1.82 with the statement "I have commented on Oronamin C's ad through comments on YouTube". However, it can be seen that the overall customer engagement variable is in a good category. 


\subsection{Simple Linear Regression Test}

A regression test is used to test whether there is an influence between one variable and another. This study, it shows that a $\beta$ coefficient is a form of a regression equation such as. The constant is 0.032 , meaning that if the ad has a value of 0 , the value of customer engagement is 0.032 . The regression coefficient for the advertising variable is 1.457 , which means that if the ad increases by one unit, customer engagement will increase by 1.457 .

Then the hypothesis test using the T-test is used to determine the variable $X$ affects the variable $y$. As in table 6 , the $\mathrm{t}$ count is 9,484 , the $\mathrm{t}$ table in 98 is 1.984 . So that $\mathrm{t}$ count is $9.484>$ from 1.984 , meaning that Ho is rejected and $\mathrm{Ha}$ is accepted. It can be concluded that there is an effect of advertising on customer engagement.

To form a commitment and consumer trust, producers must make advertisements according to their products. Advertisements that are made must also be in an informative form because consumers will not be separated from the information in a product. Not only informative, but advertising must also be made as creative as possible so that it can be different from other advertisements. With complete information packaged in unique advertisements and different from other advertisements, consumers will be more interested and will always remember how producers convey information on their products. That way the interest in buying these products increases and increases customer engagement with an advertisement.

\section{DISCUSSION}

The purpose of this study is to explain whether there is an effect between the Desktop version of Oronamin C Ads and Customer Engagement. This study used a sample of 100 respondents. The results that have been tested indicate that there is an influence between advertising having an influence on Customer Engagement. Through the correlation test, it can be seen that the correlation value tested by the two variables has a strong relationship. This is evidenced with the results of linear regression calculations which show the sig level of 0,000 and the t-test result is greater than the t table $(9,484>1,984)$. The coefficient of determination test shows the magnitude of the effect of advertising on customer engagement, through the coefficient of determination test the result is $47.9 \%$. Based on these results, it means that advertising positively affects customer engagement in accordance with the hypothesis that was previously outlined. Good advertising is one of the important things for Oronamin $\mathrm{C}$ to compete in the digital world with other products.

Based on the results of the descriptive analysis of the 3rd statement, the advertising variable can be seen as quite good because it has a good mean score with the highest score of 3.49. The statement is "The content presented by Oronamin $\mathrm{C}$ ads is different from other advertisements". This statement is in the Unexpected dimension on the Uniqueness indicator. According to Hakim in [8]
Unexpected is an unexpected or unique advertisement that can stick in the minds of consumers. So that the ads served by Oronamin $\mathrm{C}$ on YouTube look interesting and different from advertisements for other products. Meanwhile, the lowest score is in statement 21 , namely 1.82 with the statement "I have commented on Oronamin C's ad through comments on YouTube". However, it can be seen that the overall customer engagement variable is in the good category.

From the Determination Analysis test or R square, it gets 0.479 . So it can be concluded that the influence of $47.9 \%$ of Oronamin $\mathrm{C}$ advertisements affects customer engagement. If seen from the results of the correlation test research, it is proven that the correlation value tested by the advertising variable and customer engagement has a strong relationship. In addition, Oronamin C's ad has a strong effect on customer engagement. It can be proven from the calculation of Simple Linear Regression which shows a significance level of 0.000 and $\mathrm{t}$ is greater than table 9.484> 1.984 .

According to [11] the message that is conveyed in an accurate and good advertisement of a product is a very influential thing on the creation of useful advertising information for the product which includes product quality, price, and the product can be reached and how to use it correctly so that a major consideration for consumers to buy.

According to Sashi, C. M in [12] engagement is formed when consumers feel their needs are fulfilled so they will become loyal. And indirectly they will share positive experiences through social media. Customer engagement will occur when affective commitment or trust and calculative commitment, as well as a commitment between consumers and the company, has a good relationship. After creating engagement, it will influence the consumer's decision to choose a product in that one brand.

To form a commitment and consumer trust, producers must make advertisements according to their products. Advertisements that are made must also be in an informative form because consumers will not be separated from the information in a product. Not only informative, advertising must also be made as creative as possible so that it can be different from other advertisements. With complete information packaged in unique advertisements and different from other advertisements, consumers will be more interested and will always remember how producers convey information on their products. That way the interest in buying these products increases and increases customer engagement with an advertisement.

According to Shimp in [13], effective advertising must be persuasive, persuasive occurs when advertising can provide benefits and benefits. Then the ad must also be unique, honest, not using excessive ideas, and include the consumer's point of view. Ads are unique and not exaggerated like advertisements that are different from other advertisements. And also don't overdo it in terms of visual ads that don't make sense to consumers. So that makes the advertisement very redundant, it makes it difficult for consumers to understand the content of the advertising message. 
This study used a survey method with a quantitative approach. To get results that understand the social phenomena and symptoms that occur on the YouTube video Oronamin C, the researchers used quantitative methods research. This research used to pretest and posttest experiments. The first measurement used a pretest with 30 participating respondents to find out that the statements made by researchers were valid and realistic. After knowing valid and reliable, the researcher conducted a posttest on 100 respondents and the results were tested for validity, reliability, classical assumption test, simple linear regression, analysis of determination, and correlation. Researchers used the Google Form application to distribute questionnaires.

Testing the validity of the pretest part was carried out using 30 respondents with a significant level of $5 \%$ and $\mathrm{R}$ table 0.374 . After being tested, it can be seen that there are 4 invalid statements so that the researcher takes the treatment by deleting invalid statements. Furthermore, the validity of the posttest section was carried out using 100 respondents with a significant level of $5 \%$ and $\mathrm{R}$ table 0.195 . After testing the validity of these data, 22 statements were tested valid.

After doing the validity test, the researcher also tested the reliability. The result of the pretest reliability test with 30 respondents is 0.920 , so it can be concluded that $0.920>0.8$ and the statement of this research is good reliable. Furthermore, the researcher conducted a reliability test on the posttest with 100 respondents who were 0.913 , so it could be concluded that $0.913>0.8$ and the statement of this research was good reliable.

The results that have been tested indicate that there is an influence between advertising having an influence on Customer Engagement. through the correlation test, it can be seen that the correlation value tested by the two variables has a strong relationship. The results of linear regression calculations that show the sig level of 0,000 and the results of the t-test are greater than the t table (9.484> 1.984).

Based on the results of the descriptive analysis, the third statement is that the advertising variable can be seen quite well because it has a good mean score with the highest score of 3.49. The statement is "The content presented by Oronamin C advertisements is different from other advertisements". Meanwhile, the lowest score is in statement 21 , namely 1.82 with the statement "I have commented on Oronamin C's ad through comments on YouTube".

\section{CONCLUSION}

Based on the results of research that has been done by the author, the conclusion of the author is that it can be proven that there is a positive influence between the desktop version of Oronamin $\mathrm{C}$ advertisement with Customer Engagement. Researchers can conclude that the desktop version of Oronamin $\mathrm{C}$ ads has an effect on customer engagement because the ads displayed on YouTube can attract the attention of the audience.
Researchers also have suggestions obtained from the conclusions that researchers have made, namely for Oronamin C (Otsuka) to make advertisements that are more inviting to buy Oronamin $\mathrm{C}$ products. broader and add other variables, such as purchase intention, brand awareness, brand trust.

\section{ACKNOWLEDGMENT}

The author would like to thank all the people who have supported during the author's doing this research, then also to family, relatives, friends, respondents who have helped and were involved in conducting this research.

\section{REFERENCES}

[1] M. Wicaksono and N. Seminari, "Pengaruh Iklan Dan Word of Mouth Terhadap Brand Awareness Traveloka," E-Jurnal Manaj. Unud, vol. 5, no. 8, p. 250770, 2016, [Online]. Available: https://scholar.google.com/scholar?hl=en\&as_sdt $=0 \% 2$ $\mathrm{C} 5 \& \mathrm{q}=$ Pengaruh+Iklan+Dan+Word+of+Mouth+Terhad $a p+B r a n d+$ Awareness+Traveloka\&btnG=.

[2] Y. Ramadhani, "Mengapa Media Sosial Jadi Sarana Menjual Produk?," 22 Agustus, 2017. https://tirto.id/mengapa-media-sosial-jadi-saranamenjual-produk-cu46 (accessed Sep. 05, 2020).

[3] D. Anugrah, "Visual Report Masa Depan Di Tangan Generasi Z," 2017. https://tirto.id/tirto-visual-reportmasa-depan-di-tangan-generasi-z-ctMM (accessed Sep. $15,2020)$.

[4] L. Pomalaa, Y. T. Mursityo, and A. D. Herlambang, "Analisis Faktor Brand Awareness, Brand Exposure, Customer Engagement, dan Electronic Word-of-Mouth Dalam Pemasaran Melalui Media Sosial Pada The Body Shop Indonesia," J. Pengemb. Teknol. Inf. dan Ilmu Komput. Univ. Brawijaya, vol. 2, no. 10, pp. 4082-4091, 2018, [Online]. Available: http://j-ptiik.ub.ac.id/index. php /j-ptiik/article/view/2843/1086.

[5] Y. Muhamin, "Pengaruh Iklan Digital Dan Kesadaran Merek Terhadap Keputusan Pembelian Produk Pada Perusahaan Jd . Id Universitas Sumatra Utara Skripsi Oleh : Yahya Muhaimin Fakultas Ekonomi Dan Bisnis Universitas Medan Area Medan," Medan Area, 2019. 
[6] J. A. D. D. Limandono, "Pengaruh Content Marketing Dan Event Marketing Terhadap Customer Engagement Dengan Sosial Media Marketing Sebagai Variabel Moderasi Di Pakuwon City," J. Strateg. Pemasar., vol. 5, no. 1, p. 11, 2018, [Online]. Available: http://publication.petra.ac.id/index.php/manajemenpemasaran/article/view/6316.

[7] E. H. Susanto, "Dinamika pesan iklan," Komun. Univ. Tarumanagara, vol. VI, no. 2, pp. 1-9, 2014, [Online]. Available: https://journal.untar.ac.id/index. php/komunikasi/article/view/28/10.

[8] J. R. Priana, "Pengaruh Iklan ' Introduction: Jo \& Jek ' Di Youtube Terhadap Brand Awareness (Studi Kasus Perusahaan GO-Jek)," J. Entrep. Manag. Ind., vol. 2, no. 4, 2019, doi: http://dx.doi.org/10.36782/jemi.v2i4.1961.

[9] F. Abiyyuansyah and A. Irawan, "Analisis Implementasi Strategi Content Marketing Dalam Meningkatkan Customer Engagement ( Studi pada Strategi Content Marketing Amstirdam Coffee Malang )," Adm. Bisnis, vol. 73, no. 1, pp. 78-87, 2019, [Online]. Available: http://administrasibisnis.studentjournal.ub. ac.id/index.php/jab/article/view/2905/3289.

[10] Sugiyono, Metode Penelitian Pendidikan Pendekatan Kuantitatif, Kualitatif, Dan R\&D. Bandung: Alfabeta, 2015.

[11] M. Aqsa, "Pengaruh Iklan Online Terhadap Sikap Dan Minat Beli Konsumen Secara Online Di Kota Palopo (Survei pada Pengguna Internet di Kota Palopo)," Pros. Semin. Nas., vol. 03, no. 1, pp. 82-93, 2017, [Online]. Available: https://journal.uncp.ac.id/index. php/proceding/article/view/826.

[12] W. S. Suyitno and D. Dharmayanti, "Pengaruh Marketing Capability terhadap Competititve Advantage melalui Customer Engagement dan Perceived Value sebagai variabel intervening pada PT Nutrifood Indoneisa di Surabaya," J. Manaj. Pemasar., vol. 4, no. 1, pp. 1-7, 2015, [Online]. Available: http://publication. petra.ac.id/index.php/manajemen-pemasaran/article/ view/5120.

[13] E. D. Santoso and N. Larasati, "Benarkah Iklan Online Efektif Untuk Digunakan Dalam Promosi Perusahaan," J. Ilm. Bisnis dan Ekon. Asia, vol. 13, no. 1, pp. 28-36, 2019, doi: 10.32812/jibeka.v13i1.99. 